\title{
Forgiveness as a mediator on the effect of self-compassion on the ego depletion
}

\author{
Agus Abdul Rahman, ${ }^{1 *}$ Elvariana Valencia Arisanti, ${ }^{2}$ Nurul Fajriyah Prahastuti, ${ }^{3}$ \\ Nani Nuranisah Djamal ${ }^{4}$ \\ 1,2,3,4 Faculty of Psychology, Universitas Islam Negeri Sunan Gunung Djati, Bandung - Indonesia
}

\begin{abstract}
Self-compassion is a trait that helps people to withstand stressful situations. Self-compassion helps people to maintain self-regulation, to interpret the positive side of the problems, and to avoid ego depletion. The purpose of this research is to examine the indirect effect of self-compassion to ego depletion with forgiveness as a mediating variable. Forgiveness selected as a mediating variable because of its ability to play a role as a coping strategy and reduce ego depletion tendency. The researcher believes that the impact of self-compassion to ego depletion increasing if forgiveness included as a mediating variable. This research used a regression technique analysis. Data were collected on 200 students by purposive sampling technique using a self-compassion scale, ego depletion scale, and forgiveness scale. The result shows that the impact of self-compassion to ego depletion decreased without forgiveness as a mediating variable. The researcher concluded that forgiveness was effective as a mediating variable to self-compassion and ego depletion.
\end{abstract}

Keywords: ego depletion; forgiveness; self-compassion

\begin{abstract}
Abstrak: Self-compassion merupakan sifat yang dapat membantu seorang individu untuk bertahan dalam suatu tekanan. Self-compassion dapat membuat seorang individu mampu meregulasi dirinya dengan baik, dan menginterpretasikan suatu masalah secara positif sehingga cenderung terhindar dari ego depletion. Tujuan penelitian ini menguji pengaruh tidak langsung self-compassion terhadap ego depletion dengan melalui forgiveness. Forgiveness dipilih karena mampu berperan sebagai strategi coping dalam mengatasi suatu masalah, dan mampu menurunkan kecenderungan ego depletion. Subjek penelitian sebanyak 200 mahasiswa yang diambil dengan teknik purposive sampling. Instrumen pengukuran yang digunakan adalah skala self-compassion, skala state ego depletion, dan skala forgiveness. Penelitian ini dilakukan dengan menggunakan teknik analisis statistik regresi dengan mediator. Hasil penelitian menunjukkan bahwa pengaruh self-compassion terhadap ego depletion lebih kecil daripada pengaruh self-compassion terhadap ego depletion melalui forgiveness. Kesimpulan dari penelitian ini adalah forgiveness terbukti secara signifikan dapat menjadi variabel mediator pengaruh self-compassion dalam menurunkan ego depletion.
\end{abstract}

Kata Kunci: kasih sayang diri; pemaafan; penipisan ego

\footnotetext{
*Corresponding Author: Agus Abdul Rahman (e-mail: agus.abdulrahman@uinsgd.ac.id), Faculty of Psychology, Universitas Islam Negeri Sunan Gunung Djati. Jl. A.H. Nasution No.105, Bandung 40614, Indonesia.
} 


\section{Introduction}

The individual will go through adolescence and face many changes in their journey to adulthood. The wider social environment, interacting with more people, including the demand to be able to no longer play a role as children. Increased activities and tasks invite the consequences that individual adolescents can have difficulty managing themselves properly. This is because psychological aspects within oneself are developing, such as the emergence of frustration, stress, selfblame, and negative emotions often become attacks on oneself which in turn causes psychological dysfunction.

Self-compassion exists as a trait that serves to protect themselves from various negative evaluations to themselves. The trait is an element that is fixed in personality. Rosyidi (2015) mentioned that traits are predisposing to respond equally to similar groups of stimuli, which direct consistent behavior across time and place. The trait is stable in adult individuals but has relevance to adolescent (Neff \& McGehee, 2010). Trait stability will develop optimally with management since adolescence in each experience passed.

Traits as personality characteristics can be identified by showing the forms of feelings, attitudes, and behaviors that arise, and can be known by looking at the responses of responses on a psychological scale. Self-compassion arises like a trait that does not blame themselves when environmental conditions are painful and difficult to deal with (Neff \& McGehee, 2010). Individuals who use self-compassion well will be able to protect themselves from obsessions to give sharp and excessive criticism of themselves when they realize they have made mistakes.

The role of self-compassion is also important so that individuals do not give excessive criticism when expectations do not match the circumstances and do not hurt the personal ego for an achievement (Akin, 2010). As a sense of common humanity, self-compassion emerges as a way of thinking that imperfection is a human thing that is part of the experience of human life (Neff \& McGehee, 2010). Throughout its development, individuals learn from experiences in life, both successes, and failures. Giving a good attitude to yourself is a means of practice to strengthen the trait of self-compassion as an adult later.

Trait self-compassion provides intrapersonal and interpersonal advantages. Self-compassion provides an opportunity for individuals to prioritize themselves on the problems being faced, rather than focusing on other people's problems (Klingle \& Van Vliet, 2019). The focus to solve the problems being faced will train how to think, manage moods, and how to respect yourself (Klingle \& Van Vliet, 2019). Meanwhile, selfcompassion needs to be present when individuals interact with people in the social environment. Individuals will be able to minimize conflict with others when themselves get into trouble, stay involved in fun activities, maintain the quality of interpersonal relationships, and even still show an attractive side of themselves, such as physical cleanliness and appear attractive (Klingle \& Van Vliet, 2019).

In this study aspect of self-compassion consist of self-kindness, self-judgment, common humanity, isolation, mindfulness, and over-identification (Neff, 2003). First, self-kindness is the ability to treat oneself lovingly, gently, understand problems and self-deficiencies, and not judge when individuals face problems (López et al., 2015; Neff, 2003; Neff \& McGehee, 2010) Self-kindness can change the effect of negative self-feelings into positive selffeelings (Neff, 2003). Individuals will be able to give attention and affection to themselves, so they have confidence that in a state of decline and overwhelmed by problems, he deserves to be loved. 
Second, self-judgment will emerge when the individual realizes that he or she has made a mistake, incapacity, excessively identifies thoughts and feelings of being trapped, and if the feeling is allowed to lead to psychopathology (Oliveira, Ferreira, Mendes, \& Marta-Simões, 2017). Third, common humanity is a good attitude towards oneself and sees the experience as part of human life (Neff, 2003). Isolation is a sense of solitude, loneliness, separation, and helplessness because they know they have made a mistake (Neff, 2003). Fourth, mindfulness is an experience of interpreting the momentum that is happening without giving excessive assessment and dramatization (Neff \& McGehee, 2010). Mindfulness can also be said to be an awareness and balance of what is experienced now rather than excessively identifying pain and bad thoughts (López et al., 2015). Mindfulness is useful so that individuals are not obsessed with making negative thoughts and negative emotion formulation (Neff \& McGehee, 2010). These things if not prevented will bring individuals to reduce the functioning of mental health in themselves.

The concept of self-compassion is a combination of 3 components in which there are two opposing aspects. The first component consists of self-kindness versus self-judgment, the second component is common humanity versus isolation, and the third component is mindfulness versus over-identification (Neff, 2003). The result of López et al., (2015) showed that the components of self-kindness, common humanity, and mindfulness were positive factors of self-compassion, while self-judgment, isolation, and over-identification were negative factors.

Self-compassion can be a motivator so that individuals are motivated to improve their current situation. Motivation to change for the better is not just a manifestation of denial or dissatisfaction, but a consideration of alternative improvements as a form of self-love (Klingle \& Van Vliet, 2019). Trait Self-compassion is very useful for protecting individuals in daily life.

The ego-depletion itself is a term that can be translated as ego exhaustion. Individuals experience ego fatigue due to the exhaustion of their energy (Sims, 2013). Ego depletion is a condition where the self does not have the proper capacity to function as a normal and optimal condition (Baumeister \& Vohs, 2007). The condition of individuals who experience ego depletion will decrease their capacity, so the quality of psychological and physical conditions will decrease. Individuals who experience ego depletion have shown an attitude of giving up easily if they have a task to complete, it is easier to agree on the opinions of others and difficult to concentrate (Baumeister \& Heatherton, 1996; Undarwati et al,, 2017). Ego depletion occurs because of personal demands, social demands, self-control, duty demands, and family problems (Undarwati et al., 2017). Ego depletion can occur due to a variety of circumstances and at any time. Ideally, individuals can protect themselves, so that the negative impact of ego depletion will be minimized.

The ego-depletion can be shown from how individuals do attention control, emotional control, mind control, impulse control, cognitive processes, the process of choosing and willingness (Hagger, Wood, Stiff, \& Chatzisarantis, 2010). When individuals experience ego depletion, their attitudes and behavior will become biased, give up more quickly when faced with tasks, and behave unethically (Baumeister \& Heatherton, 1996). Ego depletion with high levels will reduce productivity, daily performance, and harm, so it needs to be controlled and reduced. Individuals need a barrier to protect themselves from the bad influence of ego depletion, strengthening aspects of self-compas- 
sion is expected to inhibit and reduce it. Forgiveness is an effective mediator variable for ego depletion. But it is necessary to prove the effect of self-compassion on ego depletion and whether that influence will be greater if it is done directly or indirectly, through intermediaries of other psychological variables. The purpose of adding these mediator variables is to ensure the role of these variables on the dependent variable. This is important because human psychology is not only influenced by one variable.

Forgiveness is a psychological variable that has a direct and indirect role (Hirsch, Webb, \& Jeglic, 2012). According to Hirsch et al., (2012), the direct effect of forgiveness is related to rumination, negative emotions, and anger. Meanwhile, to play the role in indirect effect, forgiveness becomes a mediating variable for social support, healthy living behaviors, functioning interpersonal relationships, and mental health.

Forgiveness is a will to solve problems without demanding compensation and help achieve social harmony (Hirsch et al., 2012; Setiyana, 2013). Forgiveness is done by changing negative thoughts, feelings, and behaviors into positive ones so that it helps someone calm down in life. Forgiveness or forgiveness is intended for those who are considered annoying, both others and themselves.

There are three aspects of forgiveness, revenge motivation, avoidance motivation, and benevolence motivation (McCullough, 2000). McCullough (2000) stated that revenge motivation means decreasing the desire to revenge others, avoidance motivation is the decreasing desire to avoid others, and benevolence motivation is the desire to do good things and make peace with others.

Forgiveness is an attitude of forgiveness and can be given to self-forgiveness. In everyday life filled with stressors, individuals who can forgive mistakes they have made will be free from ego pressure. Forgiveness in this study has a role as a mediator variable. Mediator variables have the function of delivering the effect of independent variables on the dependent variable (Antara, Kencana, \& Jayanegara, 2013). The higher the forgiveness attribute a person has, the more the self-compassion will influence the ego depletion.

This research has theoretical benefits and practical benefits. The theoretical benefit of this research is that it adds psychology to the role of self-compassion against ego depletion with forgiveness as a mediator variable. The practical benefits of this research can understand the issue of self-compassion, forgiveness, and ego depletion, especially in late adolescent and early adult individuals, to be applied in daily life.

The hypothesis proposed in this study is selfcompassion gives a negative role to ego depletion with increased forgiveness as a mediator variable.

\section{Method}

This study uses three types of scales for each psychological variable measured. Forgiveness variable measurement is measured by forgiveness scale consisting of aspects of avoidance motivations, revenge motivations, and benevolence motivations (McCullough, 2000). The instrument used to measure the self-compassion variable is the Self-compassion Scale.

The scale is the result of the translation from the original version of the Self-compassion Scale covering aspects of self-kindness, self-judgment, common humanity, isolation, mindfulness, and over-identification (Neff, 2003). The instrument used to measure ego depletion is the State Ego depletion Scale which has been translated into Indonesian. The scale was developed with aspects of the Ego depletion according to Hagger et al,, (2010).

Self-compassion in this study functions as an independent variable. The ego-depletion acts as the dependent variable. Forgiveness in this study 


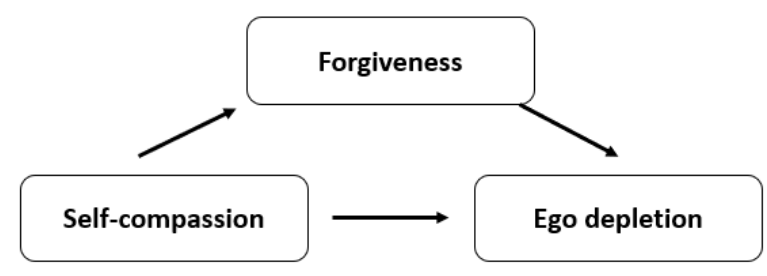

Figure 1.

Research Analysis Design

functions as a mediator variable. Data analysis in this study used mediation analysis with the help of IBM SPSS Statistics 21. Mediation analysis was carried out by performing regression analysis in stages.

In the first stage, researchers conducted a regression analysis using the self-compassion variable as an independent variable and ego depletion as the dependent variable. The result of the analysis is referred to as path $\mathrm{C}$ which is a direct effect of self-compassion on forgiveness. The second stage, researchers conducted a regression technique using self-compassion as an independent variable and forgiveness as the dependent variable as path $\mathrm{A}$. In the third stage, the researcher conducted a regression technique using self-compassion and forgiveness as the independent variable and ego depletion as the dependent variable, as path $B$ and path $C$. In the final stage, the researcher calculates the sum of the direct effects and indirect effects. The direct effect is obtained from path $\mathrm{C}$, the indirect effect is obtained from the product of path $A$ and path $B$.

\section{Results}

Study result 1

Research in Study 1 aimed to obtain information on the total item correlation for each scale and the reliability coefficient.
The forgiveness scale used in this study has 12 items with a reliability coefficient of 0.93 . The item's discrimination index of forgiveness scale items is in the range of 0.49 to 0.74 . The SelfCompassion Scale has a reliability coefficient of 0.86 with items discrimination index of 0.2 to 0.58 . The Ego depletion scale has a reliability coefficient of 0.88 with an item's discrimination index of 0.25 to 0.63 .

The result of the reliability estimation analysis was conducted using Alpha-Cronbach internal consistency approach. All three scales indicated that the reliability coefficient has a value above 0.8 and falls into the good category (López et al., 2015). It can be concluded that the three scales used in this research were reliable.

Study result 2

The result of the study can be shown in Table 1. The researcher obtained the result of the regression analysis for paths $\mathrm{A}, \mathrm{B}, \mathrm{C}$, and $\mathrm{C}^{\prime}$ and calculated the direct and indirect effects.

To prove the functioning of forgiveness as a mediator variable, researchers compute to obtain a total effect.

\footnotetext{
Total effect $=$ direct effect + indirect effect

Total effect $=c^{\prime}+(\mathrm{ax} b)$

Total effect $=-0,541+(-0,490 \times 0,192)$

Total effect $=-0,541+(-0,094)$

Total effect $=-0,635$
} 
Table 1.

Different power of Item and scale reliability coefficient

\begin{tabular}{lll}
\hline Scale & Item discrimination index & $\begin{array}{l}\text { Reliability } \\
\text { coefficient }\end{array}$ \\
\hline Self-compassion Scale & $0,2-0,58$ & 0,86 \\
Forgiveness Scale & $0,49-0,74$ & 0,93 \\
Ego depletion Scale & $0,25-0,63$ & 0,88 \\
\hline
\end{tabular}

Table 2.

Beta Coefficients and Standard Errors

\begin{tabular}{llr}
\hline Path & $B(s t d)$ & Significance \\
\hline a & $-0,490$ & $p<0,01$ \\
b & 0,192 & $p<0,01$ \\
$c$ & $-0,633$ & $p<0,01$ \\
$c^{\prime}$ & $-0,541$ & $p<0,01$ \\
\hline
\end{tabular}

Based on these calculations it is known that the total effect obtained is -0.635 and the value is greater than the direct effect of the path $c$.

The researcher also uses other ways to show the role of mediators, using the significance of indirect effects. Researchers used the Sobel Test (Preacher \& Leonardelli, 2001) obtained a statistical test value of 2.88 with $\mathrm{p}<0.01$.

Hence, it can be concluded that forgiveness is proven to mediate the relationship between selfcompassion and ego depletion.

\section{Discussion}

This study predicts the role of self-compassion on ego depletion by being mediated by forgiveness. The result showed that the effect of self-compassion on ego depletion would be greater when forgiveness was added as a mediator variable. It can be stated that the level of self-compassion influence on ego depletion, will depend on the quality of forgiveness.

Hirsch et al. (2012) stated that forgiveness has an important role as a moderator variable for various self attributes. Forgiveness has been studied and is effective as a mediating variable for reducing depression, pent-up anger, expressed anger, and suicidal behavior (Hirsch et al., 2012).

An incomplete forgiveness process can cause individuals to experience various negative emotions, reduce mental health, physical health, and various physical complaints when an individual is exposed to a stressor (Hirsch et al., 2012). Individuals who have the motivation and forgiveness capacity are found to have good physical health and well-being (McCullough, 2000).

Self-compassion in this study was found to be negatively related to ego depletion. Self-compassion can improve mental health by reducing the tendency of dysfunction to interpret negative situations that are useful to activate the psychophysiological threat system Johnson \& O'Brien, 2013). The positive components of self-compassion (self-kindness, common humanity, and mindfulness) are useful against negative self-evaluation, social withdrawal, distress Johnson \& O’Brien, 2013; Neff, 2003). The trait of self-compassion is known to have helped individuals to monitor their health, know when to need help to stay physically fit, and make individuals focus on goals (Terry \& Leary, 2011). 
In this study, the subject is a psychology student. Based on the result of interviews with 5 subjects, it was found that the studying they had to undergo demanded that they show an attitude that was responsible for their assignments or their tasks, even in a bad emotional state. The professional attitude that must be shown. According to (Syafira \& Paramastri, 2018), students who experience ego depletion are characterized by frequent complaints about learning difficulties and loss of learning concentration.

The manifestation of ego depletion in personal matters also arises in the world of education (Syafira \& Paramastri, 2018). Researchers found out that some students can minimize the impact caused by ego depletion experienced. One model stated that the impact of ego depletion can be minimized, one of which is to do self-control exercises (Baumeister \& Heatherton, 1996). High self-compassion trait as a result of self-control exercises is also one that can minimize the impact of ego depletion.

The cause of ego depletion is self-control continuously (Jones, 2014). Psychology students in the practicum process have many demands that require self-control, such as demands to be able to understand the situation experienced by the practicum object, a psychology student should have a sense of empathy to understand what is felt by the practicum object. A psychology student should also have compassion so that he or she can understand the situation experienced by the practicum object and give him or her the strength and enthusiasm in solving the problems he or she faces.

In a learning process, a student has various goals that must be pursued. The learning process slowly but surely will shape students into adult individuals who are not only smart in mastering knowledge but also self-management. It is hoped that as time passes students will be trained to strengthen the trait of self-compassion, to become forgiving individuals so that they do not need to experience ego fatigue or at least can reduce the level of ego fatigue that is experienced.

\section{Conclusion}

Self-compassion significantly negative effect on ego depletion, seen from $-0,634$ with $\mathrm{p}<0.01$. By having high self-compassion, individuals will be able to fend off the negative effects of ego depletion. The direct effect of self-compassion on ego depletion will be maximized if forgiveness is included as a mediator variable. In this study, forgiveness was proven to mediate the relationship between self-compassion and ego depletion, known from the total effect of -0.635 with $p<0.01$ and the result of the Sobel-Test which produced test statistics of 2.88 with $p<0.01$. The researchers concluded that in increasing ego depletion, selfcompassion increases forgiveness first before increasing ego depletion. The result of this study reinforces previous findings.

In the literature review mentioned in this study, self-compassion consists of positive and negative components. These two components can be explored and developed as a further study material. The effect of self-compassion on ego depletion in this study proved to be significant. The use of other mediator variables is highly recommended to see the effect of self-compassion on ego depletion.]

\section{References}

Akin, A. (2010). Self-compassion and loneliness. International Online Journal of Educational Sciences, 702-718. https://doi.org/10.1.1.422.382 
Agus Abdul Rahman, Elvariana Valencia Arisanti, Nurul Fajriyah Prahastuti, Nani Nuranisah Djamal

Antara, I. K. G., Kencana, I. P. E. N., \& Jayanegara, K. (2013). Variabel laten sebagai moderator dan mediator dalam hubungan kausal. E-Jurnal Matematika, 2(4), 33. https://doi.org/10.24843/ mtk.2013.v02.i04.p056

Baumeister, R. F., \& Heatherton, T. F. (1996). Self-regulation failure: An overview. Psychological Inquiry, 7(1), 1-15. https://doi.org/10.1207/s15327965pli0701_1

Baumeister, R. F., \& Vohs, K. D. (2007). Self-regulation, ego depletion, and motivation. Social and Personality Psychology Compass, 1(1), 115-128. https://doi.org/10.1111/j.1751-9004.2007. 00001.x

Hagger, M. S., Wood, C., Stiff, C., \& Chatzisarantis, N. L. D. (2010). Ego depletion and the strength model of self-control: A meta-analysis. Psychological Bulletin, 136(4), 495-525. https://doi.org/10.1037/ a0019486

Hirsch, J. K., Webb, J. R., \& Jeglic, E. L. (2012). Forgiveness as a moderator of the association between anger expression and suicidal behaviour. Mental Health, Religion and Culture, 15(3), 279-300. https://doi.org/10.1080/13674676.2011.571666

Johnson, E. A., \& O’Brien, K. A. (2013). Self-compassion soothes the savage ego-threat system: Effects on negative affect, shame, rumination, and depressive symptoms. Journal of Social and Clinical Psychology, 32(9), 939-963. https://doi.org/10.1521/jscp.2013.32.9.939

Jones, M. K. (2014). Self-compassion and self-control: Is self-compassion possible after ego depletion? Towson University.

Klingle, K. E., \& Van Vliet, K. J. (2019). Self-compassion from the adolescent perspective: A qualitative study. Journal of Adolescent Research, 34(3), 323-346. https://doi.org/10.1177/ 0743558417722768

López, A., Sanderman, R., Smink, A., Zhang, Y., van Sonderen, E., Ranchor, A., \& Schroevers, M. J. (2015). A Reconsideration of the Self-Compassion Scale's Total Score: Self-compassion versus selfcriticism. PLOS ONE, 10(7), e0132940. https://doi.org/10.1371/journal.pone.0132940

McCullough, M. E. (2000). Forgiveness as human strength: Theory, measurement, and links to wellbeing. Journal of Social and Clinical Psychology, 19(1), 43-55. https://doi.org/10.1521/ jscp.2000.19.1.43

Neff, K. D. (2003). The development and validation of a scale to measure self-compassion. Self and Identity, 2(3), 223-250. https://doi.org/10.1080/15298860309027

Neff, K. D., \& McGehee, P. (2010). Self-compassion and psychological resilience among adolescents and young adults. Self and Identity, 9(3), 225-240. https://doi.org/10.1080/15298860902979307

Oliveira, V. R., Ferreira, C., Mendes, A. L., \& Marta-Simões, J. (2017). Shame and eating psychopathology in Portuguese women: Exploring the roles of self-judgment and fears of receiving compassion. Appetite, 110, 80-85. https://doi.org/10.1016/j.appet.2016.12.012

Preacher, K. J., \& Leonardelli, G. J. (2001). Calculation for the Sobel test: An interactive calculation tool for mediation tests. Retrieved from http://quantpsy.org/sobel/sobel.htm

Rosyidi, H. (2015). Psikologi kepribadian: Paradigma traits, kognitif, behavioristik, dan humanistik. Surabaya: Jaudar Press.

Setiyana, V. Y. (2013). Forgiveness dan stres kerja terhadap perawat. Jurnal Ilmiah Psikologi Terapan, 1(2), 376-396. https://doi.org/10.22219/JIPT.V1I2.1589

Sims, S. C. (2013). Willpower and ego-depletion: How i do what i don't want to do, and why it's not (completely) my fault when i don't. Georgia State University. 
Syafira, V., \& Paramastri, I. (2018). Efektivitas pelatihan mindfulness untuk menurunkan ego depletion pada mahasiswa baru. Gadjah Mada Journal of Professional Psychology (GamaJPP), 4(1), 1-12. https://doi.org/10.22146/gamajpp.45344

Terry, M. L., \& Leary, M. R. (2011). Self-compassion, self-regulation, and health. Self and Identity, 10(3), 352-362. https://doi.org/10.1080/15298868.2011.558404

Undarwati, A., Mahabati, A., Khaerani, A. C., Hapsari, A. D., Kristanto, A. A., Stephany, E. S., \& Prawitasari, J. E. (2017). Pengukuran ego depletion berbasis indigenous psychology. Intuisi Jurnal Psikologi Ilmiah, 9(1), 67-73. https://doi.org/10.15294/intuisi.v9i1.9574 
This page intentionally left blank 